\title{
Importância da resistência osmótica na estabilidade do antígeno celular de Mycoplasma mycoides subesp. mycoides tipo LC em ensaio imunoenzimático (ELISA)
}

\author{
Osmotic resistance importance on Mycoplasma mycoides subsp. mycoides I type cellular antigen LC \\ stabilization on immunoenzymatic assay (ELISA)
}

Jackeline Oliveira Pontes Lizeu' ${ }^{1}$ Maria das Graças Miranda Danelli²

\begin{abstract}
RESUMO

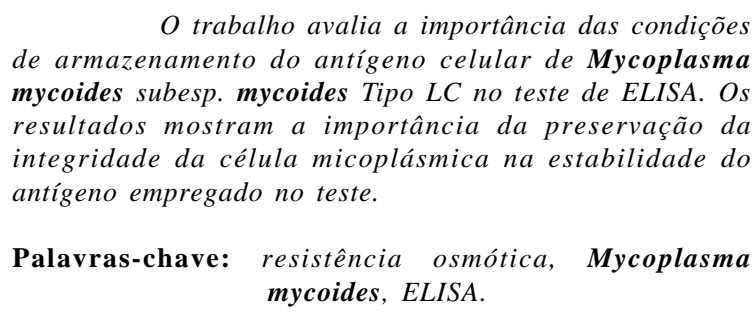

O trabalho avalia a importância das condições de armazenamento do antígeno celular de Mycoplasma mycoides subesp. mycoides Tipo LC no teste de ELISA. Os resultados mostram a importância da preservação da integridade da célula micoplásmica na estabilidade do antígeno empregado no teste.

Palavras-chave: resistência osmótica, Mycoplasma mycoides, ELISA.

- NOTA -

\section{ABSTRACT}

This work evaluates the Mycoplasma mycoides subsp. mycoides Tipo LC cellular antigen storage conditions in a ELISA test. The results show the mycoplasma cell integrity importance in antigen stability used in this test.

Key words: osmotic resistance, Mycoplasma mycoides, ELISA.

Ensaios imunoenzimáticos, em especial o teste de ELISA, são comumente utilizados na avaliação da resposta imune para micoplasmose; entretanto, a sensibilidade e a especificidade do ELISA é diretamente influenciada pela qualidade do antígeno empregado na sensibilização das placas (LIBERAL \& BOUGHTON, 1992; TULLY, 1996). Placas sensibilizadas com antígeno celular íntegro proporcionam bons resultados, especialmente em testes de triagem, porém a baixa estabilidade desse tipo de antígeno pode comprometer seu uso (BROWN et al., 1996). Desta forma, o objetivo desse trabalho foi verificar a importância da integridade da membrana celular do Mycoplasma mycoides subesp. mycoides tipo LC na estabilidade do antígeno somático no ELISA.

A amostra padrão de Mycoplasma mycoides subesp. mycoides tipo LC (MmmLC) foi cultivada como descrito previamente (BARBOSA et al., 2000). Após 18 horas de cultivo, as células foram centrifugadas a $12.000 \mathrm{xg}$ por 30 minutos a $4{ }^{\circ} \mathrm{C}$ e lavadas em solução salina ( $\mathrm{NaCl} 0,25 \mathrm{M} \mathrm{pH} 7,2)$, três vezes. O sedimento celular foi re-suspenso na mesma solução salina, correspondendo a $10 \%$ do volume total da cultura. Essa suspensão antigênica, denominada SAA, foi separada em frações e estocada a $4^{\circ} \mathrm{C}$ até o uso. Outras suspensões antigênicas, chamadas SAB1 e SAB2, foram elaboradas da seguinte forma: após a centrifugação da cultura, o sedimento celular foi lavado uma vez em solução salina gelada mais cloreto de magnésio 0,1 M, pH 7,5. O sedimento celular foi dividido em duas partes: SAB1, re-suspenso em tampão Tris-salina gelada, $\mathrm{pH} 7,5$ (Tris $0,025 \mathrm{M}, \mathrm{NaCl} 0,15 \mathrm{M}$ ); SAB2, re-suspenso em tampão $\beta$-mercaptoetanol, pH 7,4 ( $\beta$-mercaptoetanol 0,01 M, Tris 0,01M). O SAB 1 e 2 foram dividido em frações e estocado a $4^{\circ} \mathrm{C}$ até o uso.

As suspensões antigênicas (1/20) com 01, 15 e 30 dias de estocagem a $4^{\circ} \mathrm{C}$ foram analisadas por

${ }^{2}$ Professor Adjunto, Doutor, Departamento de Microbiologia e Imunologia Veterinária, Instituto de Veterinária, Universidade Federal Rural do Rio de Janeiro, BR 465, Km 07, 23851-970, Seropédica, RJ. E-mail: danelli@ufrrj.br. Autor para correspondência. 
microscopia eletrônica de transmissão (MET) e observadas em microscópio eletrônico Zeiss EM 900 (12.000 e 85.000 vezes de aumento).

A estabilidade das suspensões antigênicas no ELISA foi avaliada por dois parâmetros e duas variáveis: (1) forma de estocagem - os antígenos foram estocados a $4^{\circ} \mathrm{C}$ na forma de suspensão e como material adsorvido a microplaca; (2) tempo de sensibilização as placas sensibilizadas e estocadas a $4^{\circ} \mathrm{C}$ foram testadas no primeiro e quinto dia para SAA e, nos dias 01, 14, 21 e 28 para o SAB. Os controles negativo e positivo empregados no ELISA foram obtidos a partir de seis camundongos BALB/c, com cerca de oito semanas de idade, inoculados com $100 \mu \mathrm{g}$ de SAA por via intraperitoneal. Um pool de soros dos animais antes da imunização foi usado como controle negativo e, o controle positivo preparado a partir de um pool de soros dos animais imunizados. Os soros foram testados e titulados pelo teste de ELISA. As placas para o teste de ELISA foram sensibilizadas com $100 \mu 1$ das suspensões SSA ou SAB, contendo $2 \mu \mathrm{g}$ de proteína por mililitro de tampão carbonato de sódio $0,06 \mathrm{M}$, pH 9,6, sendo os sistemas de detecção peroxidase-IgG de cabra anticamundongo e de revelação (água oxigenada/ $\mathrm{H}_{2} \mathrm{O}_{2}$ e O-phenylenediamine dihydrochloride/OPD) empregados no teste (CASSEL \& BROWN, 1983).

A análise das suspensões antigênicas por MET revelou algumas células não íntegras na SAA, com membranas plasmáticas rompidas, similares a pequenos sacos vazios. $\mathrm{O}$ aparecimento dessas células foi diretamente proporcional ao tempo de estocagem do antígeno a $4^{\circ} \mathrm{C}$. As células íntegras, isto é, eletrondensas, estavam envoltas por uma grande quantidade de material amorfo, como pano de fundo das grades. Em contrapartida, as suspensões antigênicas SAB1 e SAB2 apresentaram poucas células não íntegras, mesmo nas suspensões armazenadas por 30 dias. O material amorfo detectado na SAA foi encontrado em quantidade moderada na $\mathrm{SAB} 1 \mathrm{e}$, em pequena quantidade na $\mathrm{SAB} 2$, revelando ser esta preparação mais estável.

A figura 1 mostra os resultados das diferentes formas e tempo de armazenamento das suspensões antigênicas no teste de ELISA. As densidades ópticas (DO) dos soros controle positivo e negativo apresentaram valores próximos, para os diferentes antígenos, quando armazenados na forma de suspensão (Figura 1A) ou na placa (Figura 1B). Quanto à análise do tempo de armazenamento dos antígenos, a SAA apresentou uma queda acentuada da D.O. já no quinto dia de armazenamento a $4^{\circ} \mathrm{C}$. As SAB1 e SAB2 mostraram uma maior estabilidade nas DO alcançadas até o 28 dia de armazenamento.

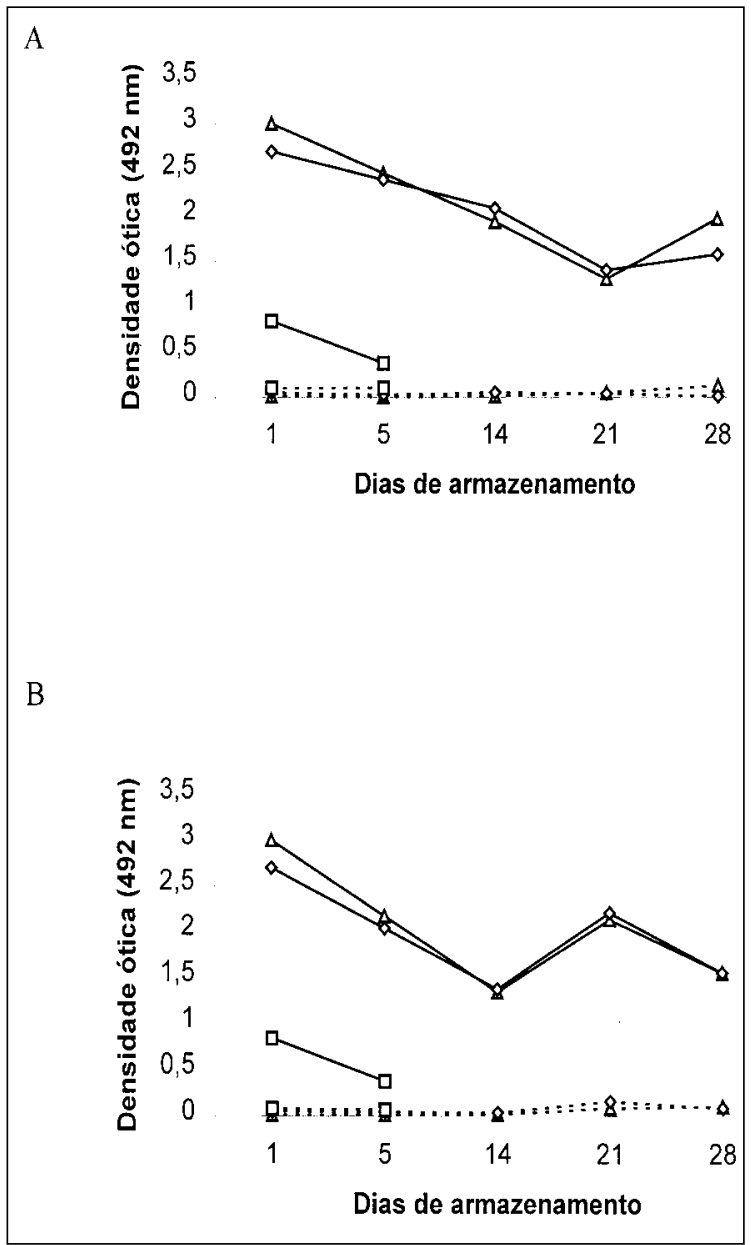

Figura 1 - Densidade ótica dos soros controles positivo $\left({ } \_\right.$) e negativo (----) no teste de ELISA para suspensð̃es antigênicas $\mathrm{SAA}(\mathrm{c}), \operatorname{SAB} 1(\Delta), \operatorname{SAB} 2(0)$ armazenado a $4{ }^{\circ} \mathrm{C}$ em suspensão (A) ou em placa (B). por 30 dias. As densidades ópticas apresentada representam a média de dois experimentos feitos e duplicata.

Os resultados alcançados mostraram que a forma de armazenamento da suspensão celular não interferiu na estabilidade da célula micoplásmica no teste de ELISA; entretanto, a solução de armazenamento é importante na promoção da estabilidade antigênica, onde o uso do tampão $\beta$ mercaptoetanol (SAB2) proporcionou uma maior estabilidade celular na MET. Este tampão é comumnete empregado em protocolos de análise enzimática, nos quais a estabilidade celular é fator determinante (POLLACK, 1998). O emprego de solução salina isosmótica tamponada com Tris (SAB1) ou o uso do tampão $\beta$-mercaptoetanol (SAB2) não promoveu diferenças relevantes nas DO obtidas no teste de ELISA. 
Os resultados sugerem que a falta de estabilidade do antígeno celular de $\boldsymbol{M}$. mycoides nos testes de ELISA é devido à falta de resistência à lise osmótica. Uma maior estabilidade do antígeno celular pode ser alcançada através do preparo e armazenamento apropriado da suspensão antigênica.

\section{AGRADECIMENTOS}

Este trabalho recebeu apoio financeiro do CNPq.

\section{REFERÊNCIAS BIBLIOGRÁFICAS}

BARBOSA, V.P. et al. Lise de Mycoplasma mycoides subesp. Mycoides tipo LC por diferentes métodos. R bras Ci Vet, v.7, p.51-54, 2000 .

BROWN, M.B.; BRADBURY, M.J.; DAVIS, J.K. ELISA in small animal hosts, rodents, and birds. In: TULLY, J.G.; RAZIN, $S$. Molecular and diagnostic procedures in mycoplasmology. London : Academic, 1996. p.93-103.

CASSEL, G.H.; BROWN. B.M.B. Enzyme-linked immunosorbent assay (ELISA) for detection of antimycoplasmal antibody. In: RAZIN, S.; TULLY, J.G. Methods in mycoplasmology. New York: Academic, 1983. V.1, p.457469.

LIBERAL, M.H.; BOUGHTON, E. Standardization of an enzyme-linked immunosorbent assay (ELISA) for the serodiagnosis of Mycoplasma bovis. Braz J Microbiol, v.23, p.146-150, 1992.

POLLACK, J.D. Enzyme analysis. In: MILES, R. NICHOLAS, R. Mycoplasma protocols. [S.1.] : Humana, 1998. p.79-94.

TULLY, J.G . Immunological tools - Introductory remarks. In: TULLY, J.G.; RAZIN, S. Molecular and diagnostic procedures in mycoplasmology. London : Academic, 1996. p.89-91. 